\title{
The effectiveness of the filial service in KPPN
}

\section{Alor}

\author{
Yulius Soleman Ferdinan Padama ${ }^{1 *}$, M. N. B. C. Neolaka ${ }^{2}$, Ajis Salim Adangdjaha ${ }^{3}$ \\ Master of Administrative Science, University of Nusa Cendana ${ }^{1,2,3}$ \\ aphepadama@gmail.com*
}

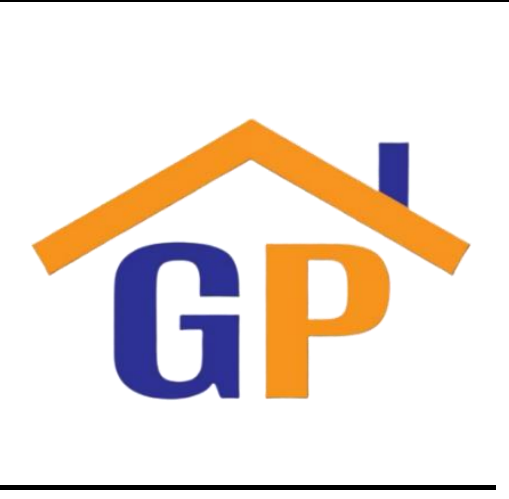

Article History

Received on 17 January 2020

$1^{\text {st }}$ Revision on 29 January 2020

$2^{\text {nd }}$ Revision on 7 February 2020

$3^{\text {rd }}$ Revision on 14 February 2020

Accepted on 2 March 2020

\begin{abstract}
Purpose: This research aims to to measure the effectiveness of the filial service in KPPN Alor which has been operating for 8 years. Measurement of the effectiveness was conducted by following two approaches: the attainment goals and the strategic constituent approaches..
\end{abstract}

Research methodology: This research is a type of case study with a qualitative approach. Research informants are KPPN Kupang employees and KPPN Filial Alor stakeholders. Measurement of effectiveness was done by approaching the achievement of objectives and strategic constituency approaches. Data were collected through observation, interviews and documentation. The analysis of data followed pattern matching techniques, while the validity of data was tested by conducting data triangulation.

Results: The results showed that the Filial Service of KPPN Alor was not effective by the attainment goal and the strategic constituent approach. There were many aspects that influenced the ineffectiveness of the Filial Service: the regulation, the policy, the quality of human resources, the service quality, and the use of information technology.

Limitations: This study measured the effectiveness of Filial Service with two approaches namely the attainment goals and the strategic constituent approaches.

Contribution: The benefits of this study are theoretically to develop the effectiveness of measurements and practically to improve and refine the filial service policy and similar policies.

Keywords: KPPN filial, The effectiveness of measurements, Public service, The treasury service

How to cite: Padama, Y. S. F., Neolaka, M.N. B. C.., Adangdjaha, A.S. (2020). The effectiveness of the filial service in KPPN Alor. International Journal of Financial Accounting and Management, 1(3), 183-189.

\section{Introduction}

Kupang State Treasury Service Office (KPPN) is a vertical agency of Directorate General of Treasury, Ministry of Finance of the Republic of Indonesia which functions as The Authority of The State General Treasurer in the regions. In carrying out its functions KPPN Kupang provides public services in the state treasury field such as APBN fund disbursement services and financial reporting. Due to the geographical condition and the accessibility issues for the stakeholders in Alor, KPPN Kupang has a long-distance service named The Filial Service KPPN Alor since 2011.

There are 17 KPPNs throughout Indonesia which are under 15 central KPPNs. The Filial Service KPPN Alor serves 26 stakeholders with a total managed budget about Rp. 202.684.993.000,in 2019. The existence of The Filial Service KPPN Alor was intended to serve the stakeholders closer so that public service can be implemented quickly. During 8 years of operation, the Filial Service KPPN Alor often received any complaints indirectly from the stakeholders about the speed of 
service, especially on the type SKPP validation service and the returns settlement of SP2D. This is the background for measuring the effectiveness of the Filial Service KPPN Alor to execute the public service in the state treasury field and the aspects that hinder and support its effectiveness, so that the policies about Filial Service in KPPN Alor can be improved and refined.

\section{Literature review and hypothesis development}

\subsection{The Concept of Effectiveness}

According to Hidayat (1986: 32) effectiveness is a measure that states how far the target (quantity, quality and time) has been achieved. The greater the percentage the targets achieved, the higher the effectiveness. According to Steers (1985), effectiveness is classified in 3 (three) models: : (1) objective optimization model, (2) system perspective, (3) stress on behavior.

Steers (1985) revealed that there are four factors influencing the effectiveness, namely organizational characteristics, environmental characteristics, worker characteristics, management policies and practices. Meanwhile, Jones and John (1995) explained several factors that influence organizational effectiveness, namely, the clarity of technology and procedures, the level of competence of staff and organizational resources, economic appreciation of staff, and mechanisms of accountability and quality organizational facilities and infrastructure.

Gie (1996) mentioned that the factors influencing organizational effectiveness include individual work motivation caused by work change, work ability, namely, the ability of individuals to deal with their work, work atmosphere, namely, the atmosphere of the organization for the relationships among individuals.

\subsection{Effectiveness Criteria}

Gibson and Donnely (1997: 32-34) argued that there are five (5) organizational effectiveness criteria, namely, production, efficiency, satisfaction, adaptation, and development.

a. Production: production describes the ability of organizations to produce the number and quality of output in accordance with environmental demands. This measure is directly related to the output consumed by the organization's customers, such as, profits, sales, documents processes, and customers.

b. Efficiency: This concept is defined as the number of comparisons between output and input. A measure of efficiency is expressed in comparisons; a comparison between profits and costs or and output or and time, which is, a common form of this measure.

c. Satisfaction: satisfaction and enthusiasm for work are similar terms that indicate how far they satisfy their employee needs. Measures of satisfaction include employees' attitudes, employees' turnover, absenteeism, lateness and complaints.

d. Adaptation: The ability of adaptation is how far the organization can respond to the internal and the external changes. If the company cannot adapt, then the sustainability of the organization will be threatened. There is no specific and tangible measure of adaptability. Management can use policies that can stimulate preparedness for change.

e. Development: The organization must invest in the organization itself to expand its ability to survive (survive) in the long-term, such as, training for management and non-management.

Campbell (as cited in Robbins, 1990: 50), also explained the organizational effectiveness criteria, namely, overall effectiveness, productivity, efficiency profit (quality, accidents/disasters, growth, absenteeism, turnover (employee turnover), job satisfaction, motivation, morale, control, conflict/ cohesion, flexibility/adaptation planning and goal setting, goal consensus, internalization of organizational goals, role and norm congruence, managerial interpersonal skills, managerial task skills, information management and communication, readiness, utilization of environment, evaluations by external entities, stability, value of human resources, participation and shared influence, training and development emphasis, and achievement emphasis.

\subsection{Effectiveness measurement approach}

Robins (1994) said that measurement of effectiveness can be done with several approaches including the goals attainment approach, system approach, strategic-constituencies approach, and competing values approach. 
1) The goals attainment approach

The goals attainment approach assumes that the organization is a unit that is created intentionally, rationally, and by purpose. Therefore, the success of goals attainment is an appropriate measure of effectiveness.

2) The system approach

The system approach to organizational effectiveness implies that the organization consists of interconnected sub-sections. If one of these sub-sections has poor performance, then there will be a negative impact on the overall system performance.

3) The strategic constituency approach

The strategic constituency approach views organizations differently. The organization is assumed to be a political arena in which the interest groups compete to control resources. In this context, the effectiveness of the organization becomes an assessment about how far organization's success is able to meet the demands of its critical constituency. The critical constituency is the parties on whom the organization depends for its sustainability in the future.

4) Competing value approach

Competing values are significantly more important than just recognition of diverse choices. The approach assumes a variety of choices that can be consolidated and organized.

In this study, the measurement of effectiveness used the attainment goals and the strategic constituent approach. The reason for using these 2 approaches are to see how far the Filial service in KPPN Alor works according to the goals set that serves the stakeholders closer and improves the service quality. Another reason is also to find out whether the existence of the Filial Service in KPPN Alor can satisfy the stakeholders, its constituents.

\subsection{The concept of public service}

\section{A. Principles of Public Service}

According to Mahmudi (2005: 234), public service provider agencies must pay attention to the principles of public service, namely, transparency, accountability, conditional, participation, nondiscriminative, balance of rights and obligations.

\section{B. Public Service Standards}

According to Ridwan and Sudrajat (2009: 103), service standards at least include service procedures, completion time, service costs, service products, facilities and infrastructure, competence of public service providers. According to Surjadi (2009: 46), excellent service basically includes four principles, namely, fast, right, cccurate, and quality.

\section{Purpose of Public Services}

According to Hayat (2017: 52), the purpose of public services is solely for the benefit of the people who receive services. For that, the services provided must be able to satisfy the community. Public satisfaction is an indicator of the merits of a public service.

\subsection{KPPN filial service concept}

According to KBBI, filial means (1) a part of the company which is located separately (especially regarding banking and shopping companies); subsidiaries, (2) branches (companies, schools, etc.), (3) bio resulting from the demolition. According to Directorate General of Treasury Regulation Number PER-7 / PB / 2012 about The Procedures of Establishment and Closure of The Filial Services and Mobile Services of KPPN, filial services are KPPN front office services that are placed outside KPPN in order to improve and serve the stakeholders closer and they carried out by a unit based on a special assignment from the head of the KPPN.

\subsection{Main duties and functions of filial KPPN}

According to PER-07- / PB-2012, the filial service has the task of carrying out the KPPN front office in a predetermined location and work area. In carrying out this task, KPPN's filial services carry out functions including:

1. SPM acceptance services along with supporting documents and ADK; 
2. Substantive and formal testing of SPM;

3. SPM scanning along with supporting documents;

4. Confirmation of receipt payment letter;

5. Reconciliation of financial statements; and

6. Customer service officer services.

\section{Research methodology}

This research used qualitative approach with a case study. Creswell (2015) argued that qualitative research design is new and dynamic. This means that the initial planning of the research cannot be established with certainty. The stages in the research process can change at any time after the researcher enters the field to collect data. Creswell stated that sometimes the research questions change in the midway to better reflect the various types of questions needed to understand the research problem(s). This then becomes the reason why researchers use qualitative methods in this study, namely, to understand more deeply the events that occur in the process of providing filial services to find out the aspects that support and inhibit filial services.

The study took place at KPPN Kupang and the Filial KPPN in Alor. The researcher also collected data from agency units that were stakeholders of Filial Service in KPPN Alor, in Kalabahi and around it. The study was conducted from September to December 2019. The research instrument was an interview guide (Interview guide), a journal, a sound / picture / video recording tool, a researcher, a book / literature / regulation. The informants were selected by using purposive sampling technique. The informants for this study included Head of KPPN Kupang, The 4th echelon official of KPPN, manager of KPPN, work unit in Alor and Filial service recipients as Stakeholders in KPPN Alor. Measurement of the effectiveness of The Filial Service KPPN Alor was done for 6 types of services selected as samples, which included:

1. Service for receiving SPM / issuance of non-salary SP2D

2. Service for receiving SPM / issuance of salary SP2D

3. SKPP approval services

4. Service for confirmation of receipt of acceptance letters

5. Financial reporting reconciliation services

6. Costumer service

The primary data sources in this study were the results from in-depth interviews and observation. The secondary data were from library sources and other references such as articles and journals. The technical data collections are interviews, observation, and documentations.

The data from this study were analyzed by following Yin's (2008) pattern matching technique. Pattern matching was done by comparing the predicted patterns with empirical patterns formed from the results of the study. The predicted pattern built from the literature review was presented in literature review and hypothesis. If there are similarities between predicted patterns and patterns of research results, they can strengthen the internal validity of a case study (Yin, 2008). In descriptive case studies, pattern matching will be relevant with that of specific variables that are predicted and determined before the data collection process.

The pattern matching technique is counter explanation as a pattern. This technique forms the pattern of certain independent variables (which have been predicted as explanations), removes the presence of other independent variables (which is predicted as a counter explanation).

Data validity testing was done by triangulation techniques namely source triangulation, triangulation of data collection techniques, and time triangulation. The research was focused on (1) Attainment of Filial KPPN goals with sub focus Budget / cost efficiency, Time efficiency, Stakeholder problem solving efficiency; (2) Fulfillment of stakeholder service needs by The Filial Service in KPPN Alor with Focus, namely, stakeholder service needs; services provided by The Filial Service in KPPN Alor. 


\section{Results and discussions}

The results of the measurement of the effectiveness of The Filial Service in KPPN Alor analyzed by following the attainment goals and the strategic constituent approach according to Robins (1994) showed that The Filial Service in KPPN Alor was ineffective, which means that The Filial Service in KPPN Alor could not achieve the goals set and the existence of KPPN was evidently unable to satisfy stakeholders maximally.

The results of the deepening of KPPN's goal showed that the Filial Service in KPPN Alor had a goal which is to create cost efficiency, time efficiency, and problem solving efficiency. The data analysis showed that there was an increase in costs to be borne by stakeholders in order to obtain treasury services, so as to result in budget inefficiencies. This cost arises because of the operational time of the Filial Service in KPPN Alor for 15 days unable to accommodate all the needs of stakeholders, especially in the matter of APBN funds disbursement, so that stakeholders in Alor had to go to the KPPN Kupang and spend a number of funds which were then accumulated in one year and spent around Rp.723, 550.000. This amount if compared to the treasury services operating cost in Alor (obtained from the budget allocation for the operational cost of The Filial Service in KPPN Alor) amounted to Rp.303,550,000, then there was an increase in cost by $138.3 \%$. This caused budget inefficiency. These costs would be increased when there was a policy of budget savings affecting the reduction in the operational budget allocation for The Filial Service in KPPN Alor. This budget reduction affected the reduction of the Filial Service in KPPN Alor operational time to 10 days. Thus more stakeholders' needs would not be accommodated by The Filial Service in KPPN Alor, so that stakeholders would spend more time in KPPN Kupang with the consequence that the budget spent would also get bigger.

Furthermore, inefficiency in service time also occured. From the research conducted on 6 samples of The Filial in KPPN Alor service types, there were violations of SOP in 3 types of services (SPM acceptance / non-salary SP2D publishing, SPM receipt / SP2D salary publishing, deposit confirmation and receipt), which caused service to be slow. The Customer service had a problem with the Human Resource Competency of Service Officer which then caused services to be slow. One type of services (SKPP approval) did not have an SOP so services could not be processed to the next stage, while another type of services (financial statement reconciliation) had used information technology so that stakeholders no longer needed The Filial Service in KPPN Alor for this type of service. Researchers call the term "Outdated Service Type".

The efficiency of resolving stakeholder concerns depends on the competency of the personnel of The Filial Service in KPPN Alor. The results showed several conditions including:

1) Stakeholder issues were resolved

2) The problems of stakeholders were not resolved

3) There was uncertainty in resolution of stakeholder problems (depending on the officer)

4) Problem solving was slow

5) They were reluctant to ask the Filial KPPN

6) Problems were forwarded to Kupang KPPN

Five of six conditions found in the study showed that there were problems in resolving stakeholder problems that caused most of the problems unresolved resolved quickly, so the problem had to be forwarded to the KPPN Kupang. The existence of The Filial Service in KPPN Alor should be able to help stakeholders solve their problems. This then led to inefficiency in resolving stakeholder problems by The Filial Service in KPPN Alor.

Meanwhile, the effectiveness of measurement with strategic constituent approach revealed that The Filial Service in KPPN Alor was ineffective because it was not able to fulfill stakeholder needs maximally. There were the stakeholders' needs that could be met with The Filial services in KPPN Alor, namely, the disbursement of APBN funds and correspondence of administration matters. The need for socialization and training could not be maximally fulfilled because the frequency of conducting socialization and training in Alor was very low. Meanwhile there were stakeholder needs related to the service quality of The Filial Service in KPPN Alor, such as, the need for speed of service, the need for service information, and problem solving needs. These needs were not fulfilled by The Filial Service in KPPN Alor with a service quality, which was not optimal. This caused dissatisfaction of services provided. 
The results of measurements of effectiveness of The Filial Service in KPPN Alor with the attainment goals approach showed that The Filial Service in KPPN Alor was ineffective because of cost inefficiency, time inefficiency and inefficient stakeholders' problem solving. Likewise, the measurement of effectiveness with the strategic constituent approach yields the same results. This is confirmed by Gibsons \& Donnely (1996: 32-34), which stated that there were five (5) organizational effectiveness criteria, one of which was Efficiency. Then, Campbell in Robbins (1990: 50) stated that there were 30 Organizational Effectiveness Criteria, one of which was efficiency. There was efficiency in The Filial Service in KPPN Alor not in accordance with public service standards as stated by Ridwan and Sudrajat (2009: 103) such as Service Procedures, Completion Time, Service Costs, Service Products, Facilities and Infrastructure, Competency of public service providers. All elements that became public service standards were not fulfilled by The Filial Service in KPPN Alor. This result was also delivered by Surjadi (2009: 46) about excellent services which included fast service, right service, accurate service, and quality service.

Based on the results of this study, we know that the aspects causing the Filial Service in KPPN Alor ineffective include:

1) The Regulations: indecisive regulations cause the reduction of service quality of The Filial Service in KPPN Alor:

a) 15-day service time causing cost inefficiency

b) SKPP validation services having no SOP for The Filial Service in KPPN Alor causing inefficient service time

2) Policy: Budget saving policy causing the operational time of KPPN Filial Alor to be reduced from 15 days to 10 days.

3) SOP Violations: SOP violations occuring in a number of types of services that caused inefficient service time.

4) The Competency of Human Resources: The competency of human resources having an impact on several things, namely, violation of SOP and the problems solving of stakeholders which caused inefficient service time.

5) Low quality of service: Low quality of service causing stakeholders unsatisfied with the services provided.

6) Use of information technology: The use of information technology causing the Filial Service in KPPN Alor to lose one of its functions, namely, reconciliation of financial statements, which has made the Filial Service in KPPN Alor ineffective.

\section{Conclusion}

This research aims to measure the effectiveness of the filial service in KPPN Alor. The results showed that the Filial Service in KPPN Alor was ineffective in providing public services. By the goals attainment approach, the Filial Service in KPPN Alor was not effective in providing treasury services in Alor because of time inefficiency, cost inefficiency and problem solving inefficiency. Meanwhile, with the strategic constituent approach, the Filial Service in KPPN Alor was quite effective to fulfill the stakeholder's needs but it still cannot create customer satisfaction. The results of this study can be used as a reference for decision making at the leadership level.

Aspects that inhibit the effectiveness of the Filial Service in KPPN Alor include regulations, policies, the competency of human resources, the service quality and the information technology. The results of this study can be used as a reference for decision making at the leadership level.

Based on the results of the study, researchers gave advice through three options, namely:

1. Option to maintain the Filial Service in KPPN Alor by making improvements including the rules/regulations, policies and the control functions, increasing the Competency of Human Resource, improving the infrastructure facilities as well as technical guidance and socialization.

2. Option to change the form of the Organization by Maximizing the use of information technology and strengthening the function of customer service.

3. The establishment of Kalabahi KPPN with the consideration the Filial Service in KPPN was not effective in providing services in Alor, which then resulted in inefficiency in terms of budget, time and problem solving. Instead, it is necessary to establish a definitive KPPN in 
the city of Kalabahi, which was preceded by a scientific study of the feasibility for establishing the KPPN Kalabahi.

\section{Limitation and study forward}

This study is limited to measure the effectiveness of The Filial Service in KPPN by only involving two approaches: the attainment goals and the strategic constituent approach.

\section{Acknowledgement}

Thank my two supervisors, Dr. Neolaka and Dr. Ajis Djaha for your guidance, also to Dr. Hendrik Toda and Dr. Nursalam for the ideas, recommendation, suggestions and criticism for this study.

\section{References}

Creswell, J. W. (2015). Penelitian kualitatif dan desain riset. Yogyakarta: Pustaka Pelajar.

Gie, The Liang. (1996). Administrasi perkantoran modern. Yogyakarta: Liberty.

Gibson, Ivancevich., \& Donnelly. (1997). Organisasi, perilaku, struktur dan proses, Jilid 1 Edisi Kedelapan. Jakarta: Bina Rupa Aksara.

Hidayat. (1986). Teori efektivitas dalam kinerja karyawan. Yogyakarta: Gadjah Mada University Press.

Hayat. (2017). Manajemen pelayanan publik. Jakarta , Raja Grafindo Persada

Jones., \& John. (1995). Working in human service organization. Australia: University of Queensland.

Mahmudi. (2005). Manajemen kinerja sektor publik. Yogyakarta: UPP AMP YKPN.

Ridwan, Juniarso., \& Sudrajat, A. S. (2009). Hukum administrasi negara dan kebijakan pelayanan publik. Bandung: Nuansa.

Robbins, SP. (1990). Perilaku organisasi. Jakarta: Prehalindo.

Robbins, SP. (1994). Teori organisasi: Struktur, desain dan aplikasi, alih bahasa jusuf udaya, Jakarta: Arcan.

Yin, R. K. (2008). Studi kasus (desain dan metode), (case study research design and methods") diterjemahkan oleh Drs. M. DjauziMudzakir, MA, Jakarta: PT.Raja Grafindo Persada.

Steers, R. M. (1985). Efektivitas organisasi (Terjemahan). Jakarta: Erlangga.

Surjadi. (2009). Pengembangan kinerja pelayanan publik. Bandung: Reflika Aditama. 